\title{
15
}

\section{Indigenous settlements and market environmentalism: An untimely coincidence?}

\author{
Fiona McCormack
}

\section{Introduction}

This chapter considers the entanglement of indigeneity and neoliberalism in Aotearoa/New Zealand in the context of fisheries. A relationship, I argue, that is mediated by market environmentalism. This is given substance in two Acts: The Treaty of Waitangi (Fisheries Claims) Settlement Act 1992, which resolved commercial claims against the Crown, and the complementary Fisheries (Kaimoana Customary Fishing) Regulations 1998, which legislated for customary fishing activities. The settlement was made feasible by the implementation of new forms of enclosures in the seascape - that is, individualised property rights, ITQs (individual transferable quota).

In this neoliberal 'opening of spaces', indigenous fisheries were repatriated as private, tradeable commodities. It is important to note, nevertheless, that Māori acceptance of quota as a way to resolve colonial alienations was an attempt to make the best of a major Treaty of Waitangi breach; the implementation of New Zealand's Quota Management System (QMS) was, in fact, by 1986 a fait accompli. There is, however, a major paradox in this settlement. Although Māori own about 33 per cent of the quota in an 
industry internationally hailed as successful (Seafood New Zealand n.d.) and three of the five companies in New Zealand (which supply 80 per cent of the catch) are Māori-owned, an ongoing sense of alienation exists from what is perceived of as an ancestral resource. I will address this contradiction in two ways. First, as Kingfisher and Maskovsky (2008) suggest, indigeneity may be just as likely to appropriate neoliberalism for its own ends as the other way round. This 'opening of spaces', incongruously, may strengthen the capacity of the state to shape and neutralise opposition. Treaty settlement processes are an example of this double-edged articulation of neoliberalism with indigeneity. Second, the use of market-based instruments, such as ITQs, is premised on a radical restructuring of human and natural worlds. This reassigns value to that generated through future trading and recreates the ontology of natural resources, making this exchangeable with wealth creation in society.

The two strands of my argument can be synthesised as follows: the resolution of Māori indigenous claims to fisheries, a neoliberal possibility, coincided with the implementation of a fisheries management regime wherein fishing rights are privatised and value arises out of market trading as opposed to harvesting fish. This articulation helps explicate the dissatisfaction many Māori currently express over fisheries: the quota system is perceived as 'broken', as 'stifling kaitiakitanga [guardianship]' and as a system wherein Māori, for the most part, perform as 'quota flickers'. ${ }^{1}$ Given that settlements are deemed 'full and final', this discontent is effectively silenced.

The empirical evidence in this chapter is drawn broadly from my research into Māori fisheries and indigenous claims over the last 15 years. This is buttressed by my more recent comparative research into ITQ systems in Iceland and Ireland and fisheries governance in Hawai $i$, the latter having no ITQ system.

The chapter is divided into three parts. The first describes the historic context surrounding the pan-Māori settlement of claims to fisheries in 1992. It highlights the interplay of privatising fishing rights and the use of quota as property to repatriate indigenous loss, and considers the resultant dichotomisation of Māori fishing interests into commercial and customary spheres. Rather than resolving colonial grievances, I suggest

1 These quotes come from interviews conducted with Māori from three different iwi in 2017 as part of my 'Iwi Settlement Quota: Opportunities and Constraints' research project. 
that the settlement has resulted in a new round of alienations, an argument I illustrate with ethnography drawn from a recent Waitangi Tribunal claim. The second section focuses critically on ITQs, the technology that connects fisheries, indigeneity and market environmentalism. It ties ITQs into the Blue Economy, an emergent meta-ideology, which seeks to identify a new wave of growth opportunities in marine and coastal ecosystems. It also considers the rise of a virtual market in fishing quota. The third section argues that the discourse of sustainability surrounding rights-based fisheries ignores, to a large extent, traditional ecological knowledge. Where indigeneity is included in ITQ systems, it is in terms of securing access to fishing rights, now recreated as quota property.

\section{Treaty of Waitangi fisheries settlement}

There is a long history of Māori opposition to the loss of their property and resources, and this is particularly the case in terms of tribal fishing rights (Bargh 2016). A sophisticated customary marine tenure system existed precolonisation, one in which boundaries demarcated tribal rohe moana (seascape), and kaitiakitanga practices (resource guardianship) included the establishment of rabui - that is, the placing of a tapu (taboo) on a seascape for conservational or political purposes, or following a death by drowning (Metge 1989). Kaimoana (seafood) was variously shared or traded depending on kinship connections and the desire to create alliances with other tribes (Ropiha 1992). Trade also occurred internationally; Māori were actively engaged in trading fish and agricultural produce both before and immediately after the signing of the Treaty of Waitangi in 1840 (Petrie 2002), and owned boats capable of sailing to Australia on a frequent basis for commercial purposes-cured fish was among the products exchanged (Waitangi Tribunal 1988: 44-66). The cultural significance of fishing also finds expression in Tangaroa, the god of the sea, and in numerous legends pertaining to ancestral activities in the seascape (see Ellison, cited in Sykes 2004, Mead \& Grove 1981, 2001).

These ownership practices, which intertwine land and sea in the same property construct, are replicated across the Pacific (Johannes 1981, Clarke 1990, Hviding 1996). In New Zealand, this linkage was inconsistent with colonial property ideologies whereby boundaries are drawn around where land meets the sea, the former being designated as susceptible to private property divisions and the latter subject to Crown ownership (Mulrennan 
\& Scott 2000). The initial opposition of Māori to ITQs made explicit the irony of this most recent enclosure. It was couched in terms of: first, on colonisation, you denied that we had tribal property rights in the sea and claimed that it was public property, then you privatise it, exclude us from these rights and assume that we never had any commercial interests in fisheries. ITQs thus give to Pākehā (New Zealand Europeans) the full, exclusive and undisturbed possession of the property right in fishing that the Crown has already guaranteed to Māori in the 1840 Treaty of Waitangi.

Māori common property constructs in fisheries were for the first time recognised as aboriginal title rights in a seminal case (Te Weehi) in $1986 .{ }^{2}$ This recognition correlated with two important reports issued by the Waitangi Tribunal following the Muriwhenua and Ngāi Tahu claims, ${ }^{3}$ and claims lodged in the High Court challenging the ITQ system. Taken together, these led to an unprecedented recognition of Māori ownership rights, in addition to evidencing an established precolonial trade in kaimoana.

In 1987 a High Court injunction was granted against the further issuing of ITQs, and government was forced into a round of negotiations with Māori litigants as an alternative to further litigation (David Williams QC, pers. comm., 2016). This resulted in the Mãori Fisheries Act 1989 (considered an interim settlement), significant for marking the moment when the Crown finally recognised that Māori have a commercial, and not just a cultural or ceremonial interest, in fisheries. Almost simultaneously, however, this recognition was undermined. This was achieved in the Act by making a legislative distinction between commercial and customary fishing rights, a distinction later formally incorporated into the Treaty of Waitangi (Fisheries Claims) Settlement Act 1992 and the Fisheries (Kaimoana Customary Fishing) Regulations 1998. The dichotomy importantly revitalised the stalled extension of ITQs by divvying up Māori fisheries interests into capitalist and non-capitalist concerns,

2 A landmark case that established that traditional Māori fishing rights could override European laws. Te Weehi v Regional Fisheries Officer [1986] 1 NZLR 680, 691-2.

3 Ngāi Tahu and Muriwhenua are tribes in the tip of the North and South islands in New Zealand. Both groups lodged fisheries claims with the Waitangi Tribunal in the 1980s. The Tribunal hearings and subsequent reports emphasise the extent of Māori fishing activities and their commercial worth, and government failure to protect them. 
commercial and subsistence interests, and private or pseudo-communal property institutions. It also identified appropriate levels of Māori society to engage with each-iwi (tribe) or hapi (sub-tribe).

ITQs synthesised Māori interests with the fisheries quota system by becoming the property right through which the 'commercial' claims were resolved. Customary practices became a separate 'non-economic' domain, primarily concerned with conservation and noteworthy for making illegal any material exchange. While an arduous application process allows for the gathering of seafood for ceremonial purposes, restricted to bui (meetings) and tangi (funerals), the regulations prohibit the exchange, barter or sale of fish-that is, they remove any semblance of trade.

Three further points about Treaty of Waitangi settlements are relevant here. First, in repatriation processes one particular form of kin entity is favoured over others. A prerequisite for settlements to proceed is that claimants 'establish a large natural group', as a means to streamline the negotiations. This prejudices smaller kin groups and ignores commentary that the basis of Māori society is hapū rather than iwi (see Ballara 1998). Claimants must also have a 'mandate' to enter into negotiations; a requirement that is complicated by the large natural group prerequisite and the fact that traditional common property rights were non-exclusive and fluid. In the post-settlement stage, there is a need to develop specific management structures, Mandated Iwi Organisations (MIOs), to handle settlement assets (New Zealand Parliament 2006). MIOs are closely aligned with maximising the chances of a successful transfer to market capitalism. Rumbles (1999) writes that these pre- and post-settlement stipulations effectively rationalise Māori social relations; Māori who undertake Treaty of Waitangi settlement processes are forced to adopt forms of organisation that are rooted in Western legal traditions (Jackson 1995).

Second, although embedded in the history and political economy of contemporary New Zealand, contrary perceptions of the Tribunal cloud the functioning of (Pākehā) civil society. Newly elected governments invariably invoke a shift in the Tribunal's financial fortunes, political and moral status, and predicted life span. The current national government, for instance, advocates direct and speedy negotiations with mandated claimant groups through the Office of Treaty Settlements (OTS). ${ }^{4}$ This undermines

4 A Labour-New Zealand First coalition government (a minority government reliant on the support of the Green Party) was elected in late September 2017. To date they appear to have taken a more cautionary approach to treaty settlements. 
not only the Tribunal but, importantly, the production of tribal history undertaken by and on behalf of Māori iwi and hapū groups; histories that crucially empower the revitalisation of group identity and provide an invaluable archival oral history resource.

Third, all settlements are categorically full and final, an insistence that generates social silencing. Silences, for instance, are created within the settlement process, as a result of the rationalisation of claimant groups, and as an outcome of the economies of previous settlements. The fisheries settlement, for example, silenced future claims to the seascape and discontent with the current regime. This silencing was explicit in the 2014 West Coast Harbour hearings I attended. These represented the collective claims of hapu and iwi from three coastal areas-Aotea, Whaingaroa and Kawhia — and are part of the Rohe Pōtae Tribunal Inquiry. Claims in the inquiry referred to historic and contemporary issues: for instance, land that was confiscated or otherwise alienated, sacred sites that were desecrated and marae (meeting house complexes) that were destroyed. Yet, the 'elephant in the room' was fisheries. Māori were concerned about the conservation of existing resources and, especially, the demise of a oncethriving local commercial fishery. In the fisheries settlement, WaikatoTainui Fisheries Ltd, the MIO of the region's largest iwi, was granted the quota that they now lease as a package, typically to large consolidated and non-local companies, the dividends from which partly trickle down to beneficiary marae. It was the incongruity of living by the sea, high rates of local unemployment, the inability to generate an income from an ancestral resource and fishing practices and policies that were perceived to be culturally irreverent and environmentally destructive that most frustrated local Māori. Tex Rickard, for instance (from Ngāti Porou on the east coast of the North Island of New Zealand, though longtime resident in Whaingaroa and husband to the late Eva Rickard of Tainui hapū), described the sea in Whaingaroa as formerly 'the people's food basket, the mainstay of local diets'. The pre-quota local commercial fisheries venture, Hartstone fisheries, he explained, had encouraged Māori employment; the company had also gifted much fish to local Māori families. Hartstone fisheries was sold simultaneously with the implementation of the quota system. The food basket, he decried, was now depleted. A result of the marketisation of fisheries and the imposition of national regulations that were unable to comprehend variations in local ecosystems. 
These issues were continually raised in the pre-hearing hui. The claimants' lawyers, while sympathetic, and professing to 'trying to figure out what angle to take, 5 were equally clear that, as dictated by existing legislation, no reference to fisheries could be made in the hearings. A silencing that obscures the existence of a pronounced and ongoing alienation. Tensions also existed over who had the mana (authority/power) to claim the harbours. Waikato-Tainui iwi argued that these fell within their tribal rohe and comprised part of their unresolved claims. Further, that the existence of a proven negotiation and a commercial body made it the most suitable, and resourced, 'large natural' body to engage with the Crown and to receive settlement assets. Their preference was to proceed to the OTS stage, thereby bypassing the Tribunal hearings. Coastal harbour hapu $\bar{u}$ and $i w i$ claimants largely disputed this and argued that the harbour claims emerged from customary interests, alternative whakapapa (genealogies) and their identity as sea people as opposed to the iwis identification with the Waikato River. ${ }^{6}$ Crucially, they rejected WaikatoTainui's claim because they perceived the $i w i$ to have mishandled fisheries and to have excluded them from the distribution of productive rights (McCormack 2016a).

\section{Fisheries governance through market environmentalism}

ITQs are the technology that connect fisheries, indigeneity and market environmentalism. They are promoted as the 'purest' example of a payment for ecosystem services in marine environments and considered a poster child for the Blue Economy. While less popularised than its sibling the Green Economy, the Blue Economy emerged out of the Rio +20 conference in 2012. The United Nations' Food and Agriculture Organization (FAO) solidified the idea with the launching of its Blue Growth Initiative in 2013, wherein Blue Growth is defined as:

the sustainable growth and development emanating from economic activities in the oceans, wetlands and coastal zones, that minimize environmental degradation, biodiversity loss and unsustainable use of living aquatic resources, and maximize economic and social benefits (FAO 2015: 8).

5 Three lawyers were present from Aurere Law in Rotorua.

6 These issues were discussed at bui I attended in Whaingaroa and Kawhai. 
The initiative addresses four key components: capture fisheries, aquaculture, livelihood and food systems (that is, access to markets and value chains), and economic growth from ecosystem services. Maria Bargh argues that the Blue Economy framework (as promoted by 'serial entrepreneur' Gunter Pauli (2010)) operates from a particular 'cultural genealogy' that 'places a focus on individual entrepreneurs and innovations rather than collectives and communal-owned operations per se' (Bargh 2014: 467). An overt future orientation displaces historical practices and traditional knowledge. Arguably, the Blue Economy accentuates the centuries-long process of enclosures in the world's fisheries by identifying a new wave of 'growth opportunities' in marine and coastal ecosystems.

Although not initially framed as a market-based mechanism to achieve environmental goals, privatisation policies in fisheries, such as ITQs, have been rebranded to meet these new prerogatives. In the context of the Blue Economy, ITQs have been incorporated as an exemplary ecosystem tool showcasing the opportunities such conversions enable. This inclusion ties ITQs into an emergent meta-ideology and implies not only a 'greening' of inherent conflicts but also a newly invigorated drive to extend their global reach (see Longo et al. 2015).

A succinct account of ITQs can be made by unpacking the acronym: thus 'I' refers to enclosures, ' $T$ ' market exchange and ' $Q$ ' the point where the science of measuring fish stocks merges with the political objective of generating wealth (see also Gibbs 2009). Where ITQs prevail, fishing effort ${ }^{7}$ is limited by the establishment of a total allowable catch (TAC). This is then divided into quota shares and distributed to various owners. Typically, when the system is first introduced, quota is freely gifted according to fishing history and/or the amount of wealth invested in the fishery. Subsequently, quota is distributed via 'the market', where it can be bought, sold and/or leased, often with the help of quota brokers and online trading systems. Owning quota guarantees a share of the TAC, and the more quota owned the larger the share. This assurance is assumed to incentivise sustainable fishing practices, reduce the danger of

7 A measure of the amount of fishing. More specifically, the amount of fishing gear of a specific type used on the fishing grounds over a given unit of time, e.g. hours trawled per day, number of hooks set per day, and so on. 
overcapitalisation and solve the problem of fishermen racing. ${ }^{8}$ The fishery, it is proposed, becomes economically efficient as less efficient operators leave the fishery, selling their quota to their more efficient counterparts. Excess capacity is thus reduced and there is an assumed increase in economic rents from a previously underproductive common property resource (see Costello et al. 2010).

ITQ fisheries are a becoming increasingly hegemonic on a global scale. That countries as spatially and culturally distinct as South Africa, Australia, Mexico and the Cook Islands have implemented ITQs and others such as Russia, Japan and Norway are moving in this direction is suggestive of two main possibilities: ITQs are able to reverse the notorious sustainability crisis in the world's fisheries; and the economic thesis on which the system is based is everywhere applicable, being compatible with local biophysical and cultural contexts, existent economic forms and human values. Neither supposition is correct. I suggest, rather, that ITQs are rooted in fantastical imaginings about the superiority of private property rights in generating good governance and economic efficiency; and that faith in the universality of 'the market' as the optimal space through which to distribute fishing rights is radically misplaced.

A shift to market environmentalism is apparent in the replacement of government regulatory standards with voluntary schemes, the growth of market-based mechanisms such as pollution permit trading schemes, the substitution of taxpayer-subsidised public good services, such as water, with full-cost consumer pricing and the growth in cost-benefit evaluations of environmental policies - the last of which created the demand for monetary valuation schemes, such as wetland banking, carbon trading and biodiversity offsets (Kallis et al. 2013). The construction of the environment as a package of ecosystem services to be assigned a monetary valuation, and to which an appropriate market-based tool can correct degradation, powerfully privileges market rationality over any other human-environment relationship. It also neatly sidesteps the critique of capitalism, and in particular its manifestation under neoliberalism, as itself heavily implicated in environmental destruction (Castree 2008, Sullivan 2013). Capitalism as a system is inherently driven to expand,

8 A race for fish is assumed to occur in the absence of individual property rights. It implies that in a common property resource fishermen will increase their effort and invest in larger boats and new technologies in order to harvest today what will not be available tomorrow. It is associated with Hardin's (2009) tragedy of the commons thesis. 
to invent new outlooks for accumulation, rendering apparently natural the internalisation into capital of previously uncommodified aspects of nature and society (Escobar 1996). As Eriksen (2016) so poignantly asks, can the world capitalist system and the 'system earth' accommodate this accelerating relational, institutional and ecological 'overheating'?

There is an obvious conceptual convergence between neoliberalism as a political-economic system and market environmentalism as a specific means through which it is actualised in nature. ITQ systems signify an early example of this union and connect a new wave of concern for the environment with the ideology of neo-classical economics; that is, the assumption that sustainability will emerge through the incentivised bargaining of those with private property allocations.

Once privatised, quota has the propensity to become activated in markets and, while there is no logical relationship between quota as property rights and free market trading, there is an assumed innate trajectory. This tendency, captured in the T (transferability) of ITQs, is perhaps its most potent characteristic. A potency that helps explicate the disjuncture between Māori property in fishing rights and the demise of fishing livelihoods. The devolution of quota to iwi began in 2004 with the implementation of the Mãori Fisheries Act. The Act set out the legislative basis for a pan-iwi distribution of fisheries settlement assets- that is, the capital and quota centrally held by Te Ohu Kai Moana ${ }^{9}$ up to that point. In order to qualify for fishing assets, iwi must set up an MIO and one or more asset-holding companies. There are currently 57 recognised MIOs, inclusive of four collective groupings of iwi (Te Ohu Kaimoana n.d.). MIO entities blend a corporate structure with a charitable trust fund complex.

Iwi Settlement Quota (ISQ) is unique: it can be conceived of as a repatriation of Māori commercial fishing rights long alienated by successive colonial governments-ISQ is thus a Treaty right. This is evidenced in the technical nomenclature used to describe ISQ: quota shares that derive from the settlement are abbreviated as SET, a reference to their Treaty settlement origins. Only quota allocated to iwi under the fisheries settlement can legally carry this title, all other quota is termed 'normal' quota (Iwi Collective Partnership n.d.). It is also distinctive in that it represents a Māori property right that preceded New Zealand's

9 The organisation set up to handle settlement assets following the 1992 commercial settlement. 
QMS. Indeed, the settlement of Māori claims to commercial fisheries strengthened the overall character of quota as property in New Zealand's ITQ. ISQ also carry different legal restrictions and statutory provisions to non-iwi-owned quota, but also to other iwi-owned assets. This makes divestment, or sale, very difficult. For instance, 75 per cent of $i w i$ members must agree to the sale of quota, and quota can only be sold to other iwi following a complicated legal process. Further, ISQ carry the mandate that wealth must be generated and subsequently distributed for the benefit of iwi members. No ISQ has been sold since allocation in 2004; quota is either fished or, more commonly, leased as an annual catch entitlement (ACE). There is an absence of Māori fishermen at all levels in the commercial industry (NZIER 2002, and from observation). Importantly, ISQ is entangled with ancestral rights and knowledge, contemporary identity and livelihood practices and accountability to future generations.

Since 2004, there has been an upsurge in the quota-leasing market. There are a number explanations for this. First, many iwi do not have the technology or capital to harvest, in particular, deep-sea fish. Second, the quota held for a particular species is often too small to sustain a local fishing venture and is leased to companies that then aggregate it. Third, iwi-owned quota packages often contain a disproportionate amount of high-volume species on the lower end of the commercially valuable spectrum; economic viability, thus, requires leasing. Fourth, while some Māori settlement quota is owned as part of a more diversified set of asset holdings, for many iwi fishing quota is their only significant asset. Thus reducing risks and reaping the highest profit from the least amount of capital input may be the only rational economic choice. Finally, more wealth can be generated from trading activities than chasing fish in the sea. Therefore, in many ways, transferability is not about fish in the sea. It concerns, rather, the emergence of virtual fish and the attendant relegation of labour as now inconsequential in generating wealth. It elevates the status of quota traders and brokers while devaluing the knowledge associated with harvesting.

In ITQ fisheries, a distinction can be made between quota holders, those who have the right to fish and/or to lease this right to others, and fishers who do the actual harvesting. If one considers the findings in other ITQ systems, such as British Columbia and Iceland, that ITQ holders made more money trading fishing rights than fishing (see Pinkerton \& Edwards 2009, Einarsson 2011), it should not be surprising that this also applies 
in New Zealand. This is true not only in activities in the quota trading market (buying and selling quota), but is also reflected in the rewards that accrue to owners who lease their quota as distinct from fishing it. An illustration of the latter is provided in the case of the panua (abalone) fishery. About 1,200 tonnes of paua are caught commercially in New Zealand each year, the majority of which is exported; export earnings are about NZ $\$ 60$ million a year. The value of paua quota has risen considerably over time. The average price of quota increased by 63.5 per cent in the first six months of trading-from NZ\$11 to NZ\$17.99 per kilo. By 2003, the average price reached NZ\$300 per kilo, 27 times the price at the start of pana quota trading in 1988. Figures for the 2014-15 year put the dollar per kilo price of quota at $\mathrm{NZ} \$ 338$. The average ACE value is $\mathrm{NZ} \$ 15.50$ per kilo whereas the port price is NZ $\$ 16.50$ per kilo; thus, after paying for the leasing arrangement, non-quota-owning harvesters receive NZ\$1 per kilo of päua sold (see Table 15.1). The ratio of the value of quota to the price of fish is approximately 23:1 (383:16.5) and the owner obtains 15-and-a-half times as much from leasing quota for one year (NZ\$15.50) than the fisher gets from harvesting (NZ\$1). Unsurprisingly, päua quota holders describe their right as akin to having won the lottery. ${ }^{10}$

Table 15.1: Pāua value in the quota market in the 2014-15 fishing year

\begin{tabular}{|l|l|l|l|}
\hline Quota/kilo & ACE/kilo & Port price/kilo & Port price-ACE \\
\hline$\$ 388$ & $\$ 15.50$ & $\$ 16.50$ & $\$ 1$ \\
\hline
\end{tabular}

Source: Author's summary.

The tension between labour and ownership in these statistics is reflected in the distinction between production and quota trading. Production, including the vertical integration of companies and the sale of fish, is a historic process. It is arguably a real, or at least visible, market whereas the quota trading system is a virtual market in which the participants buy and sell 'fish' without ever having any need to have fish to sell (sellers) or ever wishing to own fish (buyers). Fish in this instance may be considered an example of Polanyian fictitious commodity production. Quota trading, however, may be a radically different type of fiction: while

10 The data in this section comes from FishServe as part of my research on Fishing Quota and Financialisation. Since the Fisheries Act 1996, many registry-based QMS services are devolved or contracted to Seafood New Zealand (the commercial industry organisation funded by quota owner levies), as an approved government provider. FishServe is the trading name of Commercial Fisheries Services, which is a wholly owned subsidiary of Seafood New Zealand. 
there is a physical limit to the amount of fish that can be harvested, quota trading does not appear to be constrained by any obvious boundaries (McCormack 2016b).

\section{Sustainability}

Since the late 1980s, there have been endeavours to include indigenous knowledge, or traditional ecological knowledge, in sustainable development programs (Soini \& Birkeland 2014). This progression is not mirrored in the sustainability projects in rights-based fisheries. Where culture, particularly indigenous culture, is recognised in ITQ systems, it seems to be in terms of negotiating access to fishing rights - that is, property (typically in terms of a community development quota), not in the acceptance of local and traditional knowledge as a valid basis for management decisions. In New Zealand, for instance, while Māori indigenous knowledge of fisheries is recognised in non-commercial customary regulations, largely in terms of conservational features, it plays no part in the sustainability of fisheries outside of this sphere (McCormack 2010). McCarthy et al. (2014) highlight the disparity between New Zealand's internationally acclaimed fisheries management strategy and the concerns of local, in particular Māori, stakeholders. ${ }^{11}$ In their interviews with over 100 seaside inhabitants, they found very different assessments concerning the health of stocks from those reported by fisheries scientists and the commercial industry. They comment:

The locals also draw attention to a much wider suite of social and cultural consequences from unsustainable fishing than just the economic consequences emphasized by commercial interests that dominate Ministry of Primary Industry ${ }^{12}$ research and policy (McCarthy et al. 2014: 65).

Participation in the system leads to the double bind of generating wealth out of a natural resource while arguably contributing to its environmental demise. The parcelling out of a complex ecosystem as individual quota depicts fish as mere units of a resource in a spreadsheet. It recreates the

11 This research was based on quantitative interviews and aimed to investigate local perceptions of the state of New Zealand's inshore fisheries stocks and contrast this with New Zealand's international reputation concerning its fisheries.

12 Fisheries is governed in New Zealand by the Ministry of Primary Industries. Under the new Labour coalition government, the Ministry of Primary Industries has been broken into three parts: agriculture, fisheries and forestry. 
ocean ecosystem as a partible complex of commodities, quota stocks, to be cherry-picked, high-graded in ITQ terms, for consumption, or discarded as valueless. ITQ systems, for instance, are acknowledged to encourage high-grading, dumping, poaching and misreporting (Simmons et al. 2015). Despite the mooted ability of private property rights to generate sustainable practices, there is little evidence in ITQ fisheries to support this claim. As Emma Cardwell (2016, pers. comm.) notes, stewardship over the environment is very different to stewardship over the right to fish-that is, the quota right. The first requires responsible ecological behaviour, the second only responsible financial behaviour.

\section{Conclusion}

Marx's description of 'primitive accumulation' captures a process that continues unabated today, though in perhaps more insidious forms than his portrayal of it as a history written in 'letters of blood and fire' (Büscher 2009). This analysis, like Harvey's (2005) more recent conception of 'accumulation by dispossession', refers to how enclosures, which mark a separation of producers from the means of production, create a pliant and abundant proletariat and the conditions necessary for the development of capitalism. In this way, nature is imported into production and opened up to the logic of capitalism. Neoliberalisation, however, extends the reaches of classical primitive accumulation in contradictory ways. While privatisation implies the transference of resources and property from state to private ownership, for instance in fisheries, from 'the public' to quota holders, the process may not end at this point. In the context of natural resources, there may also be a provision to secure rights for the poor, as for example the community development quota assigned to indigenous groups in New Zealand, though also Western Alaska and, more recently, fishing communities in Iceland. However, as Harvey (2005) notes, this opens the door for subsequent appropriations. This can happen through outright violent dispossession, a delegitimisation of the new resource owners through legislation and, critically, 'through the market' whereby 'those who have valuable assets, but are earning incomes too low to permit social reproduction, inevitably have to sell them' (Fairhead et al. 2012: 243). Veracini adds to Harvey's list of contradictions with the concept of 'accumulation without reproduction', wherein, while work is 
required, this is increasingly within a 'political economy of promise', and as 'nonremunerated forms of labour and "voluntary servitudes" multiply, wages are less and less meant to recreate us as labour' (2015: 92).

In New Zealand, ITQ enclosures have led to further dispossessions. On a national scale, this means that fish, a commons resource, are now the private property of individuals, though, more often, corporations. As Lloyd and Wolfe point out, under the new mode of neoliberal accumulation, 'the state's role is being redrawn to furnish a conduit for the more rapid distribution of what were once public goods into the hands of corporations' (2016: 109). Dispossessions also include a disenfranchisement of smallscale and part-time Māori fishers; a delegitimising of the new resource owners through legislation, for instance, the corporate entities mandated to receive and manage quota; and the removal of exchange from customary regulations. Dispossessions, however, occur critically, through the market. Not so much in terms of the sale of quota-as in order to do so 75 per cent of $i w i$ members must agree-but in terms of leasing, a divestment not of property per se, but of reproductive labour rights and of the relationships coastal tribes have with their fisheries.

A number of commentators argue that Treaty settlements are themselves facilitating a gradual transformation of tribal hierarchies into class distinctions (see, for instance, Rata 2011). While not disagreeing with the observation that new indigenous hierarchies have arisen, and that these may articulate with the appropriation and control of material resources by a select few, I root the source of these new relations within a broader political-economic framework. The settlement of Māori fisheries rights coincided with the marketisation of fisheries, a process that has increasingly influenced the production and exchange of fish, coerced the behaviour of actors within the sector to an important degree, and elevated the status of traders and brokers while devaluing the knowledge associated with harvesting, the result being the transformation of nature into a financial derivative. Quota trading works through a radical disembedding: in this instance, disembedding the economic issue from the historical question of how to manage fisheries in a way that sustains coastal communities and the ecosystems on which they depend. 


\section{References}

Ballara A (1998). Iwi: The dynamics of Mãori tribal organisation from c. 1769 to c. 1945, Victoria University Press, Wellington.

Bargh B (2016). The struggle for Mãori fishing rights: Te ika a Mãori, Huia, New Zealand.

Bargh M (2014). A blue economy for Aotearoa New Zealand? Environment, development and sustainability 16(3):459-70, doi.org/10.1007/s10668-0139487-4.

Büscher B (2009). Letters of gold: Enabling primitive accumulation through neoliberal conservation. Human Geography 2(3):91-3.

Castree N (2008). Neoliberalising nature: The logics of deregulation and reregulation. Environment and Planning A: Economy and Space 40(1):131-52, doi.org/10.1068/a3999.

Clarke W (1990). Learning from the past: Traditional knowledge and sustainable development. The Contemporary Pacific 2(2):233-51.

Costello C, Lynham J, Lester SE \& Gaines SD (2010). Economic incentives and global fisheries sustainability. Resource 2:1-393, doi.org/10.1146/annurev. resource.012809.103923.

Einarsson N (2011). Culture, conflict and crises in the Icelandic fisheries: An anthropological study of people, policy and marine resources in the North Atlantic arctic. PhD thesis. Uppsala Universitet.

Eriksen TH (2016). Overheating: The world since 1991. History and Anthropology 27(5):469-87, doi.org/10.1080/02757206.2016.1218865.

Escobar A (1996). Constructing nature: Elements for a post-structural political ecology. In Peet R (ed.), Liberation ecology, Routledge, New York.

Fairhead J, Leach M \& Scoones I (2012). Green grabbing: A new appropriation of nature? Journal of Peasant Studies 39(2):237-61, doi.org/10.1080/030661 50.2012.671770.

FAO (Food and Agriculture Organization) (2015). FAO contribution to part 1 of the report of the secretary-general on oceans and the law of the sea, www.un.org/ depts/los/general_assembly/contributions_2015/FAO.pdf.

Gibbs M (2009). Individual transferable quotas and ecosystem-based fisheries management: It's all in the T. Fish and Fisheries 10(4):470-4, doi.org/10.1111/ j.1467-2979.2009.00343.x. 
Hardin G (2009). The tragedy of the commons. Journal of Natural Resources Policy Research 1(3):243-53, doi.org/10.1080/19390450903037302.

Harvey D (2005). Spaces of neoliberalization: Towards a theory of uneven geographical development, vol. 8, Franz Steiner Verlag.

Hviding E (1996). Guardians of Marovo Lagoon: Practice, place, and politics in maritime Melanesia, University of Hawai'i Press, Honolulu.

Iwi Collective Partnership (n.d.). The inconvenient truth of Maori fisheries, www. iwicollective.co.nz/the-inconvenient-truth-of-maori-fisheries/.

Jackson M (1995). Justice and political power: Reasserting Māori legal process. In Hazlehurst K (ed.), Legal pluralism and the colonial legacy: Indigenous experiences of justice in Canada, Australia, and New Zealand, Avebury, Aldershot.

Johannes R (1981). Words of the lagoon: Fishing and marine lore in Palau District of Micronesia, University of California Press, Berkeley.

Kallis G, Gómez-Baggethun E \& Zografos C (2013). To value or not to value? That is not the question. Ecological Economics 94:97-105, doi.org/10.1016/j. ecolecon.2013.07.002.

Kingfisher C \& Maskovsky J (2008). Introduction the limits of neoliberalism. Critique of Anthropology 28(2):115-26, doi.org/10.1177/0308275X08090544.

Lloyd D, \& Wolfe P (2016). Settler colonial logics and the neoliberal regime. Settler Colonial Studies 6(2):109-18, doi.org/10.1080/2201473X.2015. 1035361.

Longo SB, Clausen R \& Clark B (2015). The tragedy of the commodity: Oceans, fisheries, and aquaculture, Rutgers University Press, New Jersey.

McCarthy A, Hepburn C, Scott N, Schweikert K, Turner R \& Moller H (2014). Local people see and care most? Severe depletion of inshore fisheries and its consequences for Māori communities in New Zealand. Aquatic Conservation: Marine and Freshwater Ecosystems 24(3):369-90, doi.org/10.1002/aqc.2378.

McCormack F (2010). Fish is my daily bread: Owning and transacting in Maori fisheries. Anthropological Forum 20(1):19-39, doi.org/10.1080/ 00664670903524194.

McCormack F (2016a). Indigenous claims: Hearings, settlements, and neoliberal silencing. PoLAR: Political and Legal Anthropology Review 39(2):226-43, doi.org/10.1111/plar.12191. 
McCormack F (2016b). Quota systems: Repositioning value in New Zealand, Icelandic and Irish fisheries. In Angosto-Ferrandez L and Presterudstuen G (eds), Anthropologies of value: Cultures of accumulation across the global north and south, Pluto Press, doi.org/10.2307/j.ctt1dwstjr.14.

Mead S \& Grove N (1981). Ngā Pēpeha a ngà tīpuna: He Whakairiwhare Na. 2. Department of Māori, Victoria University, Wellington.

Mead S \& Grove N (2001). Ngā Pēpeha a ngà tīpuna: The Sayings of the Ancestors. Victoria University Press, Wellington.

Metge J (1989). Evidence of Alice Joan Metge in respect of Te Wharo Oneroa A Tohe. Submission to the Waitangi Tribunal Muriwhenua Land Report 1992, Wai $45 \mathrm{H} / \mathrm{C} 20$.

Mulrennan M \& Scott S (2000). Indigenous rights in saltwater environments. Development and Change 31(3):681-708, doi.org/10.1111/1467-7660.00172.

NZIER (New Zealand Institute of Economic Research) (2002). Preserving fisheries quota for Maori, Report to the Treaty of Waitangi Fisheries Commission, teohu. maori.nz/te_ohu/archive/allocation/Preserving\%20fisheries\%20quota\%20 for\%20Maori.pdf.

New Zealand Parliament (2006). Treaty of Waitangi settlement process, www. parliament.nz/resource/0000021392.

Pauli G (2010). The Blue Economy: 10 years, 100 innovations, 100 million jobs, Paradigm Publishers, Taos.

Petrie H (2002). Colonisation and the involution of the Maori economy. Paper presented at the XIII World Conference of Economic History, Buenos Aires, July.

Pinkerton E \& Edwards DN (2009). The elephant in the room: The hidden costs of leasing individual transferable fishing quotas. Marine Policy 33(4):707-13, doi.org/10.1016/j.marpol.2009.02.004.

Rata E (2011). Discursive strategies of the Māori tribal elite. Critique of Anthropology 31(4):359-80, doi.org/10.1177/0308275X11420116.

Ropiha J (1992). Alienation of Māori fisheries in Mahia Peninsula 1920-1990. MA thesis, University of Auckland.

Rumbles W (1999). Treaty of Waitangi settlement process: New relationship or new mask. Paper presented at the Compr(om)ising Post/colonialism(s): Challenging Narratives and Practices Conference, Wollongong, Australia, 10-13 February. 
Seafood New Zealand (n.d). Key facts, www.seafood.co.nz/our-seas/key-facts/.

Simmons G, Bremner G, Stringer C, Torkington B, Teh L, Zylich K, Zeller D, Pauly D \& Whittaker H (2015). Preliminary reconstruction of marine fisheries catches for New Zealand (1950-2010), University Of British Columbia, Vancouver.

Soini K \& Birkeland I (2014). Exploring the scientific discourse on cultural sustainability. Geoforum 51:213-23, doi.org/10.1016/j.geoforum.2013. 12.001 .

Sullivan S (2013). Banking nature? The spectacular financialisation of environmental conservation. Antipode 45(1):198-217, doi.org/10.1111/ j.1467-8330.2012.00989.x.

Sykes A (2004). Opening submission foreshore and seabed Wai 1071, Claim to the Waitangi Tribunal, Wellington, New Zealand.

Te Ohu Kaimoana (n.d.). Did you know/Iwi ika—supporting iwi fisheries, www. iwiika.maori.nz/ahc/did-you-know.htm.

Veracini, L (2015). The settler colonial present, Springer, doi.org/10.1057/ 9781137372475.

Waitangi Tribunal (1988). Muriwhenua fishing claims report (Wai 22), New Zealand Department of Justice, Wellington. 
This text is taken from The Neoliberal State, Recognition and Indigenous Rights: New paternalism to new imaginings, edited by Deirdre Howard-Wagner, Maria Bargh and Isabel AltamiranoJiménez, published 2018 by ANU Press, The Australian National University, Canberra, Australia.

doi.org/10.22459/CAEPR40.07.2018.15 